\title{
Entrapment of Rhizopus oryzae lipase displayed on Saccharomyces cerevisiae surface as whole cell biocatalyst for biodiesel synthesis
}

\author{
Wei Jia, Rui Zhang, Yun Liu* \\ Beijing University of Chemical Technology, College of Life Science and Technology, No. 15 \\ Beisanhuan East Road, Chaoyang district, Beijing 100029 China \\ * corresponding author: liuyunprivate@sina.com or liuyun@mail.buct.edu.cn
}

\begin{abstract}
Keywords:Hizopus oryzae lipase, surface display technique, whole cell catalyst, Saccharimyces cevevisiea, properties, biodiesel

ABSTRACT:In this work, the whole cell biocatalyst of Rhizopus oryzae lipase (ROL), a versatile lipase for biodiesel production, was successfully developed through surface display technique using a-agglutinin 2 (Aga2) as an anchor protein and Saccharimyces cevevisiea as anchor yeast cell. The enzyme properties of displayed ROL were systematically investigated. Results showed that the maximal value of olive oil hydrolysis activity of displayed ROL reached $78.9 \pm 2.1 \mathrm{U} / \mathrm{g}$ dried cells. It retained $93 \%$ original activity at $50{ }^{\circ} \mathrm{C}$ for $1 \mathrm{~h}$ incubation, and exhibited relatively high stability with remaining $>65 \%$ of original activity at $\mathrm{pH} 7.0$ and 8.0. Interestingly, $\mathrm{Ca}^{2+}$ could significantly enhance the displayed ROL activity by more than 1.6-fold, while other metal ions $\left(\mathrm{Na}^{+}, \mathrm{K}^{+}, \mathrm{NH}_{4}^{+}\right.$, $\mathrm{Mg}^{2+}, \mathrm{Ca}^{2+}, \mathrm{Zn}^{2+}, \mathrm{Cu}^{2+}, \mathrm{Mn}^{2+}, \mathrm{Al}^{3+}$ and $\mathrm{Fe}^{3+}$ ) showed no effects on its activity. The displayed ROL also showed higher tolerance abilities towards organic solvents and detergents in comparison with the native free ROL. Reaction kinetics showed that the parameter $V_{\max }$ of the displayed ROL was calculated to be $1.62 \mathrm{~mol} / \mathrm{L} / \mathrm{min}$, and $K_{\mathrm{m}}$ values were $14.65 \mathrm{~mol} / \mathrm{L}$ for methanol substrate and 1.18 $\mathrm{mol} / \mathrm{L}$ for soybean oil substrate, respectively. To further improve its operational stability for biodiesel production from waste cooking oil, the displayed ROL was respectively entrapped with sodium alginate (SA), sodium alginate-boric acid (SA-BA), polyvinyl alcohol-alginate-boric acid (PVA-SA-BA), and sodium alginate-glutaraldehyde (SA-GA). The highest biodiesel yield of 81.2\% was obtained by the displayed ROL entrapped with SA-GA, and retained $85 \%$ of original activity after 7-batch recycles.
\end{abstract}

\section{Introduction}

As a green and renewable energy source, biodiesel has been attracted increasing attentions throughout the world ${ }^{[1]}$. Lipase biocatalysis for biodiesel production exhibits outstanding merits over alkali or acid catalysis in that the overall transesterification process is less energy intensive and a complex process of catalyst removal and wastes treatment is not required. However, the main hurdle of a traditional biocatalysis using immobilized lipase as a catalyst is laying on its high cost. To meet this challenge, surface displaying lipase as a whole cell catalyst for biodiesel production is prominent because this technology integrates lipase fermentation prodction and immobilization in a cost-effective and simple way ${ }^{[2]}$. In the present study, using Aga2 as anchor protein, Rhizopus oryzae lipase (ROL) was successfully displayed on Saccharimyces cerevisiae cell surface to construct the whole ell catalyst for bidiesel production.

\section{Materials and Methods}

Strain and media Escherichia coli DH5a was used for plasmid construction, propagation and amplification. Cells were grown in LB medium ( $1.0 \%$ tryptone, $0.5 \%$ yeast extract and $1.0 \% \mathrm{NaCl}$ ) at $37^{\circ} \mathrm{C}$ for $14 \mathrm{~h}$. When screening transformation, $100 \mu \mathrm{g}$. $\mathrm{mL}^{-1}$ of ampicillin was added into sterilized LB medium. $R$. oryzae strain was purchased from China Industrial Microbial Preservation Center (ATCC: IFO 4697). S. cerevisiae EBY100 (Leu+ and Trp+) was gifted by Dr. Lihai Fang in our university. The yeast rich growth medium was YPD (1.0\% yeast extract, $2.0 \%$ peptone and $2.0 \%$ glucose). For solid media, agar (15\%) was added. Olive oil emulsion solution (the volume ratio of 
olive oil and $2.0 \%$ polyvinyl alcohol was 1:3) was prepared for whole cell catalyst activity measurement.

Plasmids Construction and Yeast Transformation All basic DNA manipulations including restriction digestion, ligation, and agarose gel electrophoresis were carried out with standard procedures ${ }^{[3]}$. The cell-surface expression plasmid pYD1-ROL (Fig. 1) was introduced in $S$. cerevisiae strain using Aga2 as anchor protein by electrotransformation. For the transformation, 10 $\mu \mathrm{L}$ of each DNA cassette was used. The cells were incubated at $30^{\circ} \mathrm{C}$ in YPD medium supplemented with $1 \mathrm{M}$ sorbitol solution for $1 \mathrm{~h}$ and then plated on YPD medium.

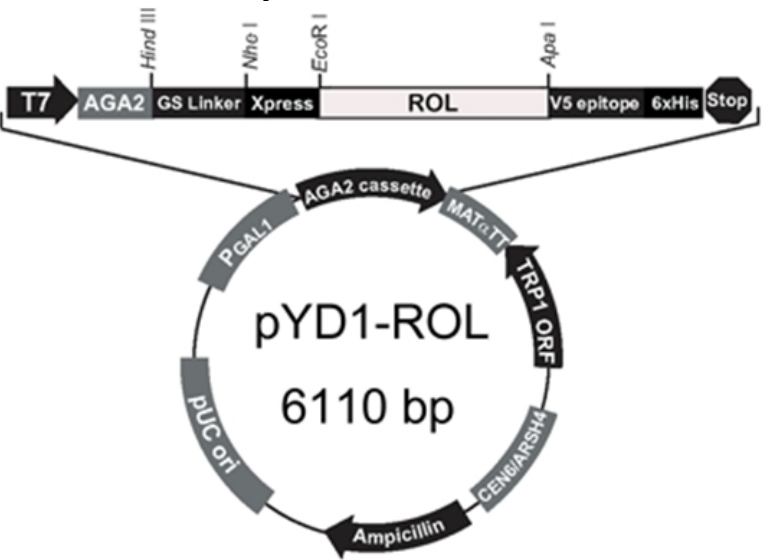

Fig. 1 The expression plasmid pYD1-ROL construction

Cultivation and activity of whole cell catalyst The $S$. cerevisiae strain harbouring the lipase cell-surface display cassette pYD1-ROL was cultivated in $50 \mathrm{~mL}$ test tubes with $10 \mathrm{ml}$ of SG+CAA medium at $200 \mathrm{rpm}$ and $20{ }^{\circ} \mathrm{C}$. Lipase activity of ROL whole cell catalyst was determined by monitoring the hydrolysis of olive oil to free fatty acids titrated by $1 \mathrm{M} \mathrm{NaOH}$.

Enzymology properties and methanolysis for biodiesel production by ROL whole cell catalyst Effects of temperature, $\mathrm{pH}$, organic solvents, and detergents on lipase activity and stability were evaluated. Furthermore, The methanolysis reaction using frying waster oils as substrate was performed to product biodiesel in 50-ml falcon tubes in a shaking incubator at 200 $\mathrm{rpm}$ and $37^{\circ} \mathrm{C}$. The lipase activity was calculated according to the reference ${ }^{[4]}$, and the biodiesel yield was measured with the method reported in the literauter ${ }^{[5]}$.

\section{Results and Discussion}

\section{Construction of ROL whole cell catalyst by surface display technique}

Aga2 gene (990 bp in length without the stop codon) fused with the gene encoding ROL (1101 bp in length without the signal sequence) was contructed plasmid pYD1-Aga2-ROL. S. cerevisiae EBY100 strain was transformed with the expression cassette pYD1-Aga2-ROL.Rhodamine hydrolysis circle, SDS-Page, immunofluorescent and flow cytometry analyses showed that ROL was successfully displayed on S. cerevisiae surface to construct a whole cell catalyst.

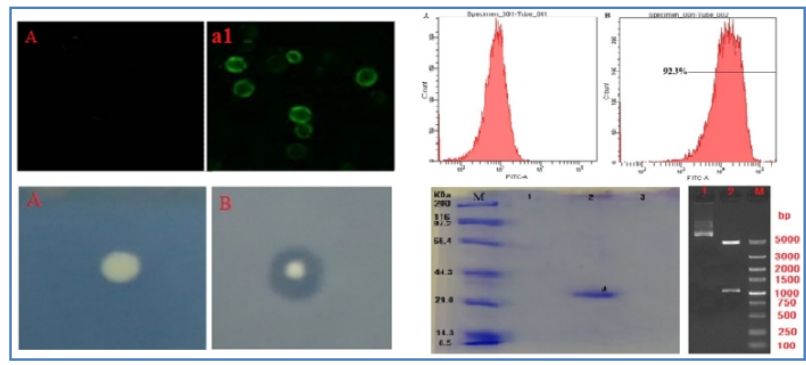

Fig. 2. The confirmation of ROL whole cell catalyst successfully displayed on S.cerevisiae surface

Characterization of the ROL whole cell catalyst The effects of temperature, $\mathrm{pH}$, metal ions, 
organic solvents and detergents on ROL whole cell catalyst were evaluated. Results showed that the highest activity of ROL whole cell catalyst was obtained to be $78.9 \mathrm{U} / \mathrm{g}$ dried cell for $72 \mathrm{~h}$ incubation. The ROL whole cell catalyst presented satisfactory thermal and $\mathrm{pH}$ stabilities, organic solvents and detergents tolerance. Metal ion $\mathrm{Ca}^{2+}$ could enhance the activity of ROL whole cell catalyst.
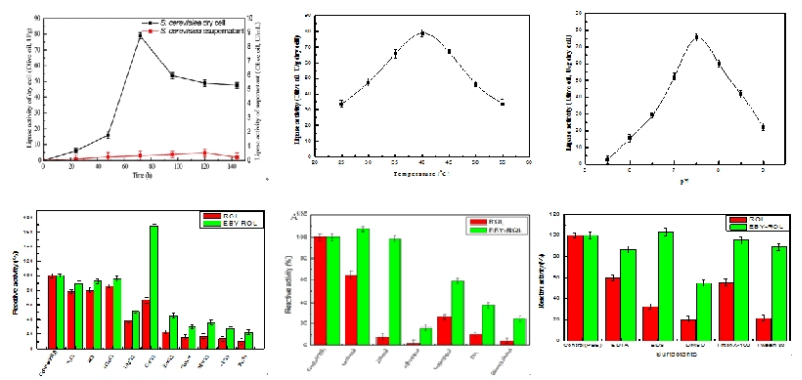

Fig. 3. Characterization of ROL whole cell catalyst

Catalysis kinetic of ROL whole cell catalyst The kinetic parameters , Vmax and Km, of ROL whole cell catatalyst were examined for methanolysis of $0.6 \mathrm{M}$ and $1.0 \mathrm{M}$ soybean oil and methanol, respectively. Results showed Vmax was $1.6 \mathrm{~mol} \cdot \mathrm{L}^{-1} \cdot \mathrm{min}^{-1}$, and $\mathrm{Km}$ for soybean and methanol was 1.2 and 14.7 mol. $\mathrm{L}^{-1}$.

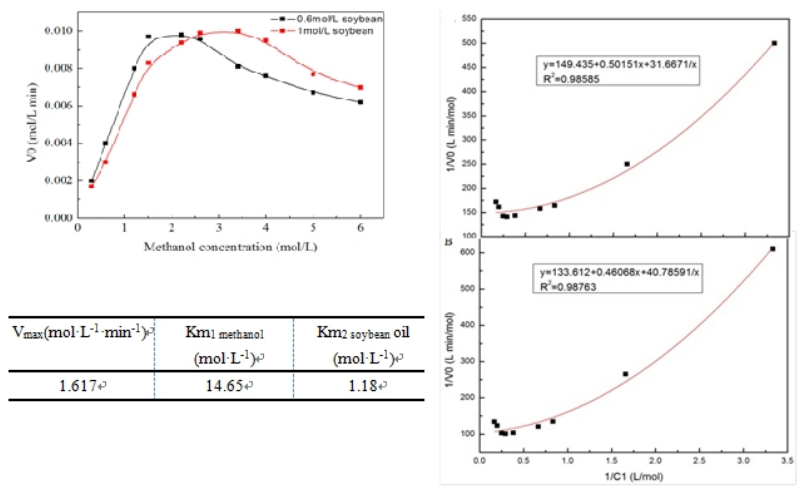

Fig. 4. Kinetics constants by non-linear fitting

Biodiesel synthesis by ROL whole Cell Biocatalyst encapsulation with sodium alginate The ROL whole cell catalyst was encapsulated with $1 \%$ sodium alginate, and four immobilized ROL whole cell catalysts were obtained, A: $1 \%$ sodium alginate- $\mathrm{CaCl}_{2} ; \mathrm{B}: 1 \%$ sodium alginate-boric acid; C: PVA-1\% sodium alginate-boric acid; D: $1 \%$ sodium alginate- glutaraldehyde. The ROL whole cell catalyst encapsulated with $1 \%$ sodium alginate- glutaraldehyde was used to produce biodiesel from fried waste oil, and biodiesel yield of $81.7 \%$ was achieved and the biocatalyst showed good operational stablity, and its activity remained more than $80 \%$ of orginal activity after 7 batch repeated usage (Fig. 5).
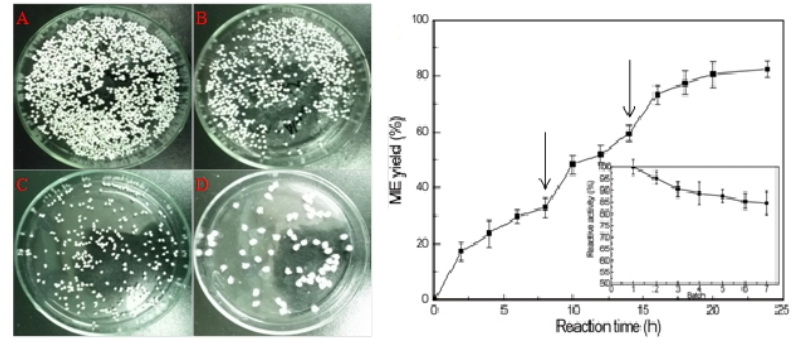

Fig. 5. ROL whole cell catalyst encapsulation with sodium alginate and its application in biodiesel production

\section{Conclusion}

Using Aga2-Aga1 of a-agglutinin as anchor protein, ROL was successfully displayed on S. 
cerevisiae cell surface to achieve the whole cell catalyst. This ROL whole-cell catalyst showed the hydrolysis activity of olive oil for the first time, and the value was $78.9 \mathrm{U} \cdot \mathrm{g}-1$ dry cell. The properties of ROL whole cell catalyst were characterized, such as temperature and its thermal stability, $\mathrm{pH}$ and $\mathrm{pH}$-stability, organic solvent tolerance, and metal ion effects. Furthermore, ROL whole cell catalyst was imbedded by alginate sodium to improve its operational stability. Results showed that the biodiesel yield of imbeded ROL whole cell catalyst was $81.2 \%$, and remained $80 \%$ of initial activity after repeating 7 batches.

\section{Acknowledgements}

The authors acknowledge the financial funds from the National Natural Science Foundation of China (NSFC31270858; 21476016).

\section{References}

[1] Y. Liu, C. Li, S. Wang, W. Chen. Solid-supported microorganism of Burkholderia cenocepacia cultured via solid state fermentation for biodiesel production: Optimization and kinetics. Applied Energy, 2014, 113: 713-721.

[2] Y. Liu, R. Zhang, Z. Lian, S. Wang, A. T. Wright. Yeast cell surface display for lipase whole cell catalyst and its applications. Journal of molecular catalysis B-Enzymatic, 2014, $106: 7-25$

[3] J. Sambrook, and D. W. Russell. Molecular cloning: a laboratory manual, 3rd ed. Cold Spring Harbor Laboratory Press, Cold Spring Harbor, 2001. pp 125-135

[4] Yun L, Chong L, Wang S, et al. Solid-supported microorganism of Burkholderia cenocepacia, cultured via solid state fermentation for biodiesel production: Optimization and kinetics[J]. Applied Energy, 2014, 113(6):713-721.

[5] Yun L, Chong L, Wang S, et al. Solid-supported microorganism of Burkholderia cenocepacia, cultured via solid state fermentation for biodiesel production: Optimization and kinetics[J]. Applied Energy, 2014, 113(6):713-721. 